\title{
EXTRACTION OF ALUMINUM (III) IONS FROM WASTE WATER USING AN ADSORBENT PREPARED FROM STEMS OF CASSIA OCCIDENTALIS PLANT
}

\author{
P. Karunasri Meghana ${ }^{1}$, Anna Aruna Kumari ${ }^{2}$, K. Venkata Pravalika ${ }^{1}$, P. \\ Janaki Sriram $^{1}$ and K. Ravindhranath ${ }^{1 *}$ \\ ${ }^{1}$ Department of Chemistry, K L University, Green Fields, \\ Vaddeswaram-522 502, Guntur Dt., A.P., India \\ ${ }^{2}$ Department of Engg. Chemistry and Post Graduate Chemistry, Bapatla Engineering College \\ (Autonomous), BAPATLA-522101, Guntur Dt., A.P., India \\ *E-mail: ravindhranath.kunta@gmail.com
}

\begin{abstract}
Bio-materials pertaining to Cassia Occidentalis plant are investigated as an adsorbent for the removal of $\mathrm{Al}^{3+}$ ions from polluted water. By controlling extraction conditions namely, $\mathrm{pH}$, adsorbent dosage, time of equilibration, rpm and temperature, $100 \%$ removal of $\mathrm{Al}$ (III) ions is achieved. Substantial amounts of $\mathrm{Al}^{3+}$ ions can be removed even at low pH values. Even tenfold excess of common co-cations and many of anions (except $\mathrm{Cl}^{-}$and $\mathrm{F}^{-}$) do not interfere in the extraction. Thermodynamic parameters are evaluated to know the nature of adsorption. The methodology developed is applied successfully for the removal of $\mathrm{Al}^{3+}$ ions from the industrial effluents and polluted water samples.
\end{abstract}

Keywords: Aluminum (III), Cassia Occidentalis, adsorption, applications

(C) RASĀYAN. All rights reserved

\section{INTRODUCTION}

The residual amounts of aluminum salts present in the effluents of various aluminum based industries are recognized as the mains source of aluminum pollution. ${ }^{1,2}$ Further, the leaching of aluminum ions from the aluminum soils and alum-treated municipal water are also the other sources of contamination. ${ }^{3,4}$ The consumption of $\mathrm{Al}$ (III) ions contaminated waters causes neurological disorders, Parkinson and Alzheimer's disease, anemia and orthopedic problems ${ }^{5}$. Further, the aquatic life such as fish, water weeds, algae, zooplankton etc is affected. ${ }^{6,7}$

Hence, the removal of $\mathrm{Al}$ (III) ions from waters assumes importance in pollution control investigations. The conventional methods based on precipitation are not effective at low concentrations while the methods based on ion-exchange, Reverse Osmosis, electro-dialysis are costly and not adoptable in large scale applications ${ }^{8-10}$. In this context, the use of bio-materials as adsorbents is an interesting aspect in view of availability, cheap and effectiveness. Investigations are made using $\mathrm{HNO}_{3}$ activated carbons of olive stones (adsorbent) along with oleic acid (surfactant) for the removal of $\mathrm{Al}$ (III) ions ${ }^{11}$. Septhum et al $(2007)^{12}$ investigated the adsorption nature of Chitosan towards Al (III) from the water. Mexent ZUE MVE et al (2016) studied the removal of $\mathrm{Al}(\mathrm{III})$ ions using active carbon of Coula edulis Nut Shell ${ }^{8}$. Javaweera et al, $2007^{13}$ investigated the extraction of Al (III) by growing water hyacinth in wetlands. Adsorbents derived from the bio-materials of Moryngea Millingtonia and Cygium Arjunum ${ }^{14}$, Acacia Melanoxylon and Eichhornia Crassipes ${ }^{15}$, Ficus Racemosa ${ }^{1}$ and Withania Somnifera ${ }^{16}$ plants are used for the extraction of Aluminum ions from waste water. Our research group is investigating these aspects of purification of polluted water and found some successful methods for the extraction of $\mathrm{F}^{-}, \mathrm{Pb}^{2+}, \mathrm{Cr}$ (VI), $\mathrm{NO}_{2}{ }^{-}, \mathrm{NH}_{3}, \mathrm{PO}_{4}{ }^{3-}$ and Dyes. ${ }^{17-31}$

Rasayan J. Chem., 12(1), 338-346(2019)

http://dx.doi.org/10.31788/RJC.2019.1215064

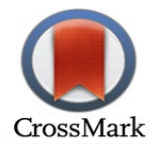


While we are investigating different bio-materials of the different plant as adsorbents for the extraction of different pollutive ions, stems of Cassia Occidentalis plant are noted to have good adsorption nature towards Al (III) ions. Hence, in this work, an adsorbent derived from Cassia Occidentalis plant stems is investigated for its adsorption nature towards $\mathrm{Al}$ (III) ions by optimizing the various conditions.

\section{Chemicals}

\section{EXPERIMENTAL}

All analytical grade chemicals were used and the solutions were prepared using double distilled water. $\mathrm{Al}^{3+}$ stock solution of concentration $100 \mathrm{mg} / \mathrm{L}$ was prepared and was diluted suitably as per the need. Buffer solutions (concentrated / diluted), Eriochrome cyanine R solution, $\mathrm{H}_{2} \mathrm{O}_{2}$ Solution (5 vol) were prepared as per the literature.

\section{Adsorbent}

Cassia occidentalis plant is an herbal plant and it belongs to Fabaceae family. It grows up to $60-150 \mathrm{~cm}$ in height and is found throughout in India. The stems of Cassia Occidentalis were cut to pieces and were thoroughly washed with distilled water. Then they were dried in sunlight and dried material was crushed to $<75$ microns. Thus obtained powdered material was activated at $105^{\circ} \mathrm{C}$ for $1 \mathrm{~h}$ in an oven and stored in an air-tight bottle. It used as an adsorbent in this investigation. Thus obtained Cassia Occidentalis Stems powder is named as COSP.

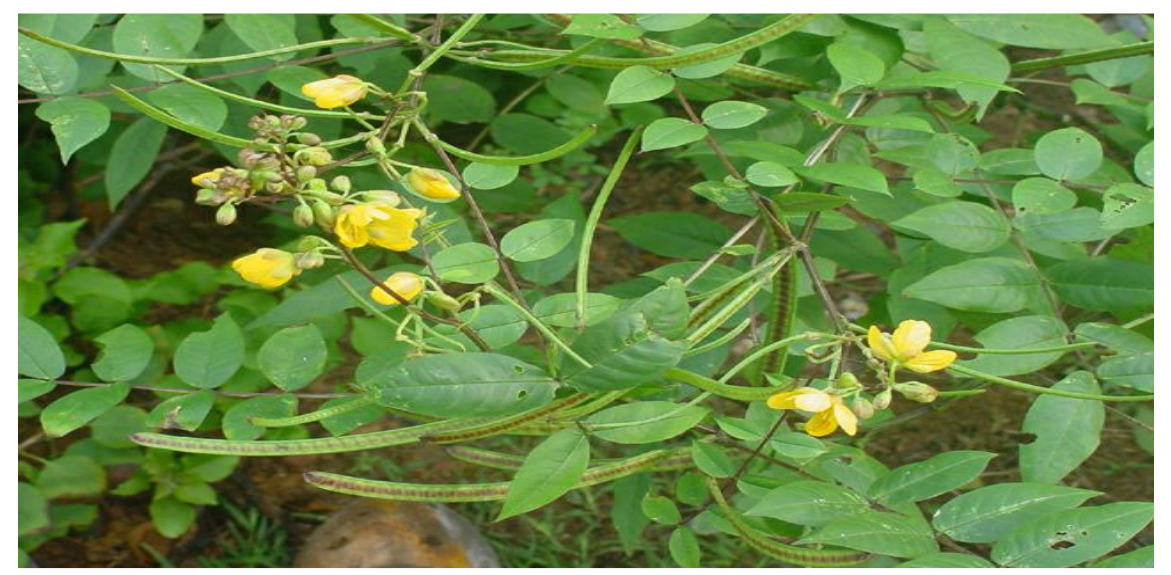

\section{Adsorption Experiment}

Fig.-1: Cassia Occidentalis Plant having an Affinity towards Al(III) Ions

Batch procedures were adopted ${ }^{28,32,33}$. Known amounts of adsorbent were added to $250 \mathrm{ml}$ of $\mathrm{Al}$ (III) solution (known concentrations) taken in stoppered $500 \mathrm{ml}$ conical flask. The initial pHs of the resulting solutions were adjusted to desired values using $\mathrm{pH}$ meter and by the addition of either dil. $\mathrm{HCl}$ or dil. $\mathrm{NaOH}$. Then the conical flasks were agitated for a definite time in mechanical agitators. After a certain equilibration time, the adsorbent was separated from the water using filtration. The remaining (unadsorbed) amount of Aluminum ions in the filtrate was assayed using the "Eriochrome cyanine R" method. ${ }^{34}$

By gradually changing the various physicochemical parameters namely, $\mathrm{pH}$ of the equilibrium mixture, equilibration time, adsorbent concentration, initial adsorbate concentration and working temperature, the optimum conditions for the maximum removal of $\mathrm{Al}(\mathrm{III})$ was assessed. The observed results with respect to these parameters were presented in Fig.-2 to 6 . The effect of co-ions on the extraction of $\mathrm{Al}^{3+}$ was studied by keeping the concentration of co-ions in ten-fold excess than the concentration of $\mathrm{Al}^{3+}$. The common ions that naturally existing were chosen for the study. The results are present in Fig.-7. The adsorption nature and adsorption kinetics were analyzed adopting well-known models and also thermodynamic studies were made. The observed results are depicted in Fig. -6 and Tables- 1 to 3. The developed method was applied to water samples collected at Aluminum Industry effluents and polluted lake waters and the observations are presented in Table- 4 . 


\section{RESULTS AND DISCUSSION}

Using COSP as an adsorbent, the extraction of $\mathrm{Al}^{3+}$ ions was studied by gradually varying the extraction parameters. The following observations are significant

\section{Effect of Agitation Time}

The influence of time of equilibration on the extraction of aluminum ions at various solution $\mathrm{pHs}$ while keeping constant the sorbent dosage $(2.5 \mathrm{~g} / \mathrm{L})$ and initial $\mathrm{Al}$ (III) concentration of $\mathrm{Al}$ ions (50 ppm), is studied and the results are presented in Fig.-2. At a fixed $\mathrm{pH}$, as the equilibration increases, $\%$ removal of $\mathrm{Al}$ (III) is increased. For instance, at pH: 8, \% removal is: $61 \%$ at $10 \mathrm{mins}, 72 \%$ at $20 \mathrm{mins}, 92 \%$ at 30 mins, $96 \%$ at 60 mins, $98 \%$ at 90 mins, $100 \%$ at 120 mins and above.

\section{The effect of Initial pH}

The influence of the initial $\mathrm{pH}$ of the equilibration mixture on $\mathrm{Al}^{3+}$ ions extraction is presented in the Fig.3. Maximum extractions are noted when the $\mathrm{pH}$ is between 6 to 8 . Decrease or increase the $\mathrm{pH}$ from this optimum range, results in the decrease of $\%$ removal of $\mathrm{Al}^{3+}$ ions. The extractability (at constant COSP dosage: $2.5 \mathrm{~g} / \mathrm{L}$; agitation time: $120 \mathrm{~min}$ ) is $56 \%$ in $1.0 \mathrm{~N} \mathrm{HCl}$ and is increased to $64.0 \%$ in $0.5 \mathrm{~N} \mathrm{HCl}$. Percentage extraction is noted to be 78 at $\mathrm{pH}: 1,90$ at $\mathrm{pH}: 2,95$ at $\mathrm{pH}: 4$ and reached $100 \%$ between $\mathrm{pH}$ : 6 to 8 . With further increase of $\mathrm{pH}$, the extractability is decreased: $85.0 \%$ at $\mathrm{pH}: 9$ and 75.0 at $\mathrm{pH} .10$.

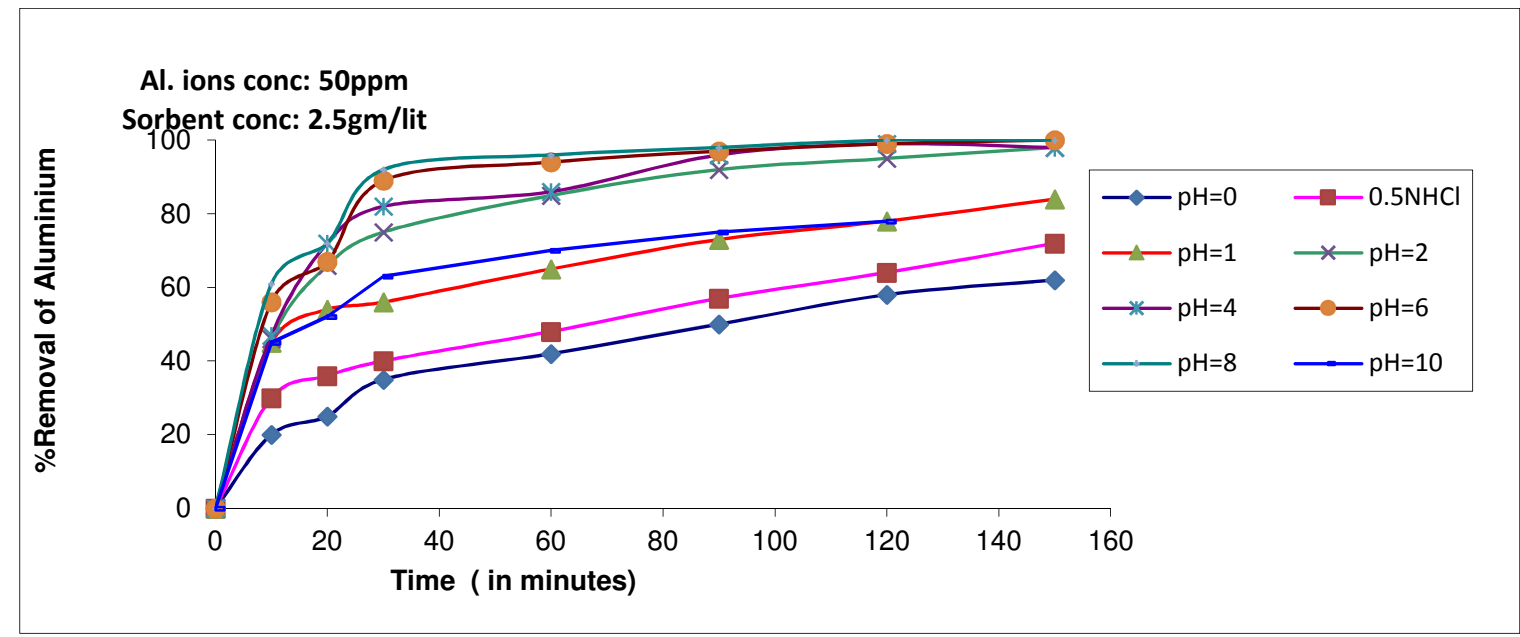

Fig.-2: Time Vs \% Removal of $\mathrm{Al}^{3+}$ Ions

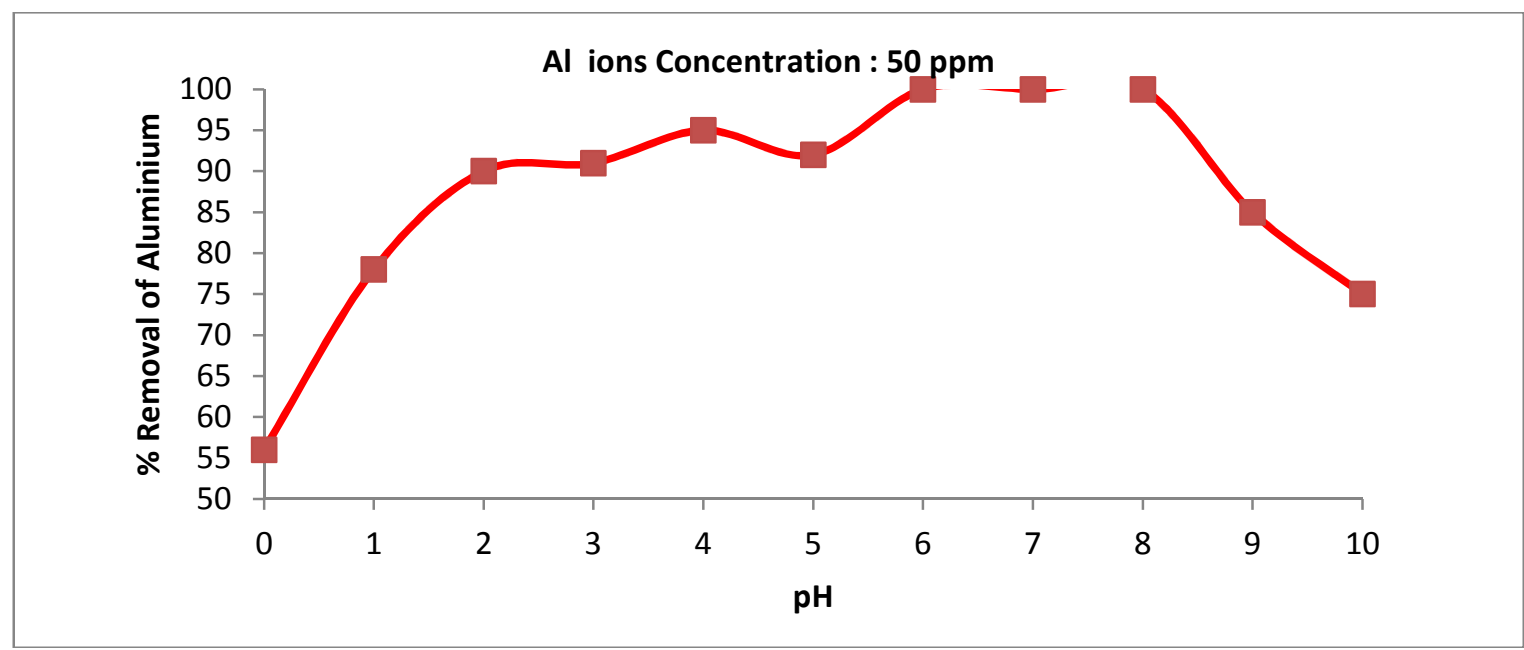

Fig.-3: $\mathrm{pH}$ Vs \% Removal of Aluminium using COSP 


\section{Sorbent Concentration}

The influence of adsorbent dosage on the extractability of $\mathrm{Al}(\mathrm{III})$ ions is studied. The observations are presented in Fig.-4. As the COSP concentration is increased, the \% of extraction is also increased: $60.0 \%$ at $0.5 \mathrm{~g} / \mathrm{L} ; 70 \%$ at $1.0 \mathrm{~g} / \mathrm{L} ; 75.0 \%$ at $1.5 \mathrm{~g} / \mathrm{L} ; 95 \%$ at $2.0 \mathrm{~g} / \mathrm{L}$ and $100 \%$ at and above $2.5 \mathrm{~g} / \mathrm{L}$. Initially, the $\%$ removal is more and it is slow down with the increase in the concentration of COSP and a study state is reached at and above $2.5 \mathrm{~g} / \mathrm{L}$ with $100 \%$ removal of $\mathrm{Al}$ (III) ions.

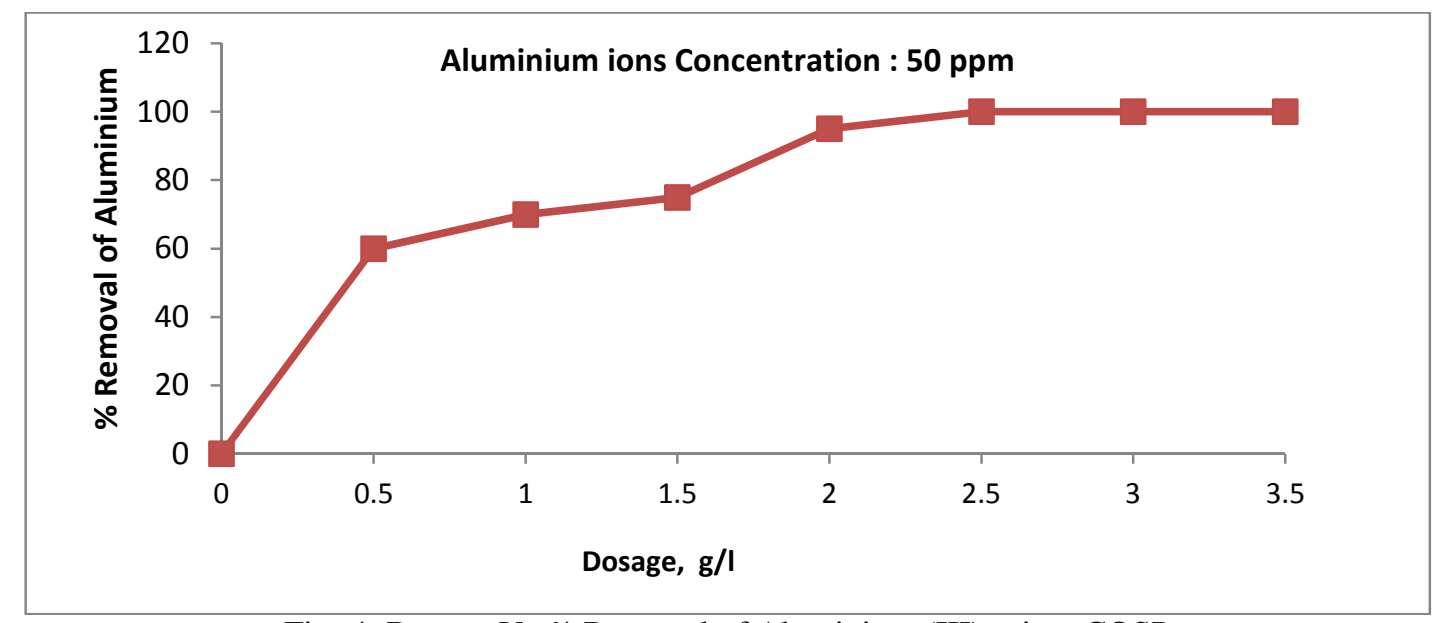

Fig.-4: Dosage Vs \% Removal of Aluminium (III) using COSP

\section{Initial Concentration Effect}

The influence of initial concentration of $\mathrm{Al}(\mathrm{III})$ on the extraction of $\mathrm{Al}$ (III) ions is studied by changing the concentration of Aluminum ions from $20 \mathrm{mg} / \mathrm{L}$ to $100 \mathrm{mg} / \mathrm{L}$ while maintaining the other extraction conditions at optimum levels namely, $\mathrm{pH}$ : 8 , equilibration time : $120 \mathrm{~min}$, COSP dosage: $2.5 \mathrm{~g} / \mathrm{L}$, rpm: 300 and temp.: $30^{\circ} \mathrm{C} \pm 2{ }^{\circ} \mathrm{C}$. The results obtained are depicted in Fig. -5 . The $\%$ removal is $100 \%$ until the initial $\mathrm{Al}^{3+}$ concentration is $50 \mathrm{mg} / \mathrm{L}$ but when it is increased more than $50 \mathrm{mg} / \mathrm{L}$, the $\%$ removal is decreased to: $90.0 \%$ at $60 \mathrm{mg} / \mathrm{L} ; 82.0 \%$ at $70 \mathrm{mg} / \mathrm{L} ; 75.0 \%$ at $80 \mathrm{mg} / \mathrm{L} ; 68.0 \%$ at $90 \mathrm{mg} / \mathrm{L} ;$ and $65.0 \%$ at $100 \mathrm{mg} / \mathrm{L}$. At low concentrations of $\mathrm{Al}^{3+}$ ions, the availability of active sites for adsorption on COSP is more and hence the removal is more. As the concentration of $\mathrm{Al}^{3+}$ ions is progressively increased, the demand for active sites is increased. But for a fixed amount of COSP, the needed active sites are not sufficiently available and so, the less removal.

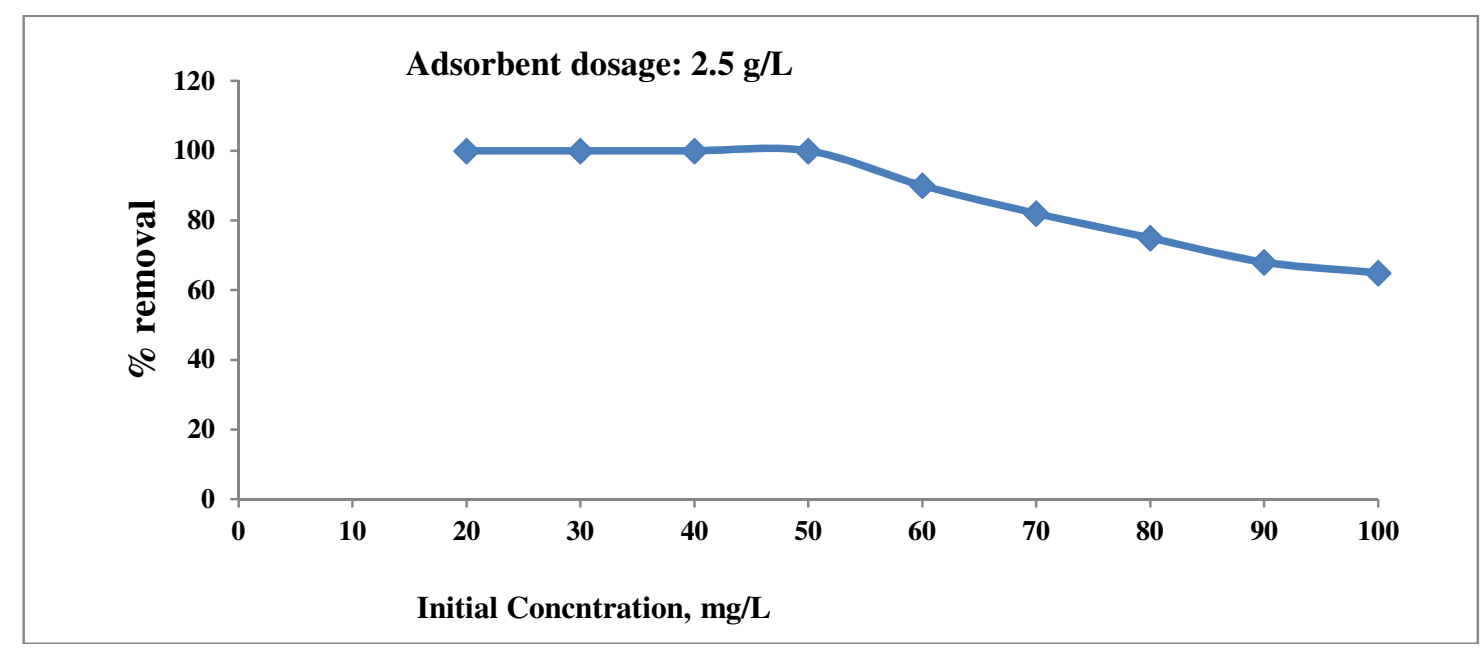

Fig.-5: Initial Concentration of $\mathrm{Al}(\mathrm{III})$ Ions Vs \% Removal of $\mathrm{Al}(\mathrm{III}$

\section{Influence of Temperature}

Percentage extraction of $\mathrm{Al}^{3+}$ ions was studied at three temperatures: 303, 313 and $323 \mathrm{~K}$.. The results are 
RASĀYAN J. Chem.

Vol. 12 | No. 1 |338 - 346| January - March | 2019

depicted in Fig.-6. It is observed that with a rise in temp from 303 to $323 \mathrm{~K}$, the percentage removal of $\mathrm{Al}$ ions increases from 92.6\% to 97.2\%. The results are presented in Fig.-6 and the calculated thermodynamic parameters in Table-1. Thermodynamics parameters namely $\Delta \mathrm{G}, \Delta \mathrm{H}$ and $\Delta \mathrm{S}$ were determined as per the equations: $\Delta \mathrm{G}=-\mathrm{RT} \ln \mathrm{K}_{\mathrm{d}} ; \ln \mathrm{K}_{\mathrm{d}}=\Delta \mathrm{S} / \mathrm{R}-\Delta \mathrm{H} / \mathrm{RT} ; \mathrm{K}_{\mathrm{d}}=\mathrm{q}_{\mathrm{e}} / \mathrm{C}_{\mathrm{e}}$ and $\Delta \mathrm{G}=\Delta \mathrm{H}-$ $\mathrm{T} \Delta \mathrm{S}$ where $\mathrm{K}_{\mathrm{d}}=$ the distribution coefficient for the adsorption, $\mathrm{q}_{\mathrm{e}}=$ the amount of $\mathrm{Al}^{3+}$ ions adsorbed per liter of solution at equilibrium, $\mathrm{C}_{\mathrm{e}}=$ the equilibrium conc. of $\mathrm{Al}^{3+}$ ion solutions, $\mathrm{T}=$ absolute temp. $\mathrm{R}=$ gas constant $17,20,28$. The values of $\Delta \mathrm{H}$ and $\Delta \mathrm{S}$ were calculated from the slope and intercept of a plot between $\ln K_{d}$ and $1 / T$ and $\Delta G$ values were calculated from the equation $\Delta \mathrm{G}=\Delta H-T \Delta S$ and presented in Table-1. ${ }^{28,33}$

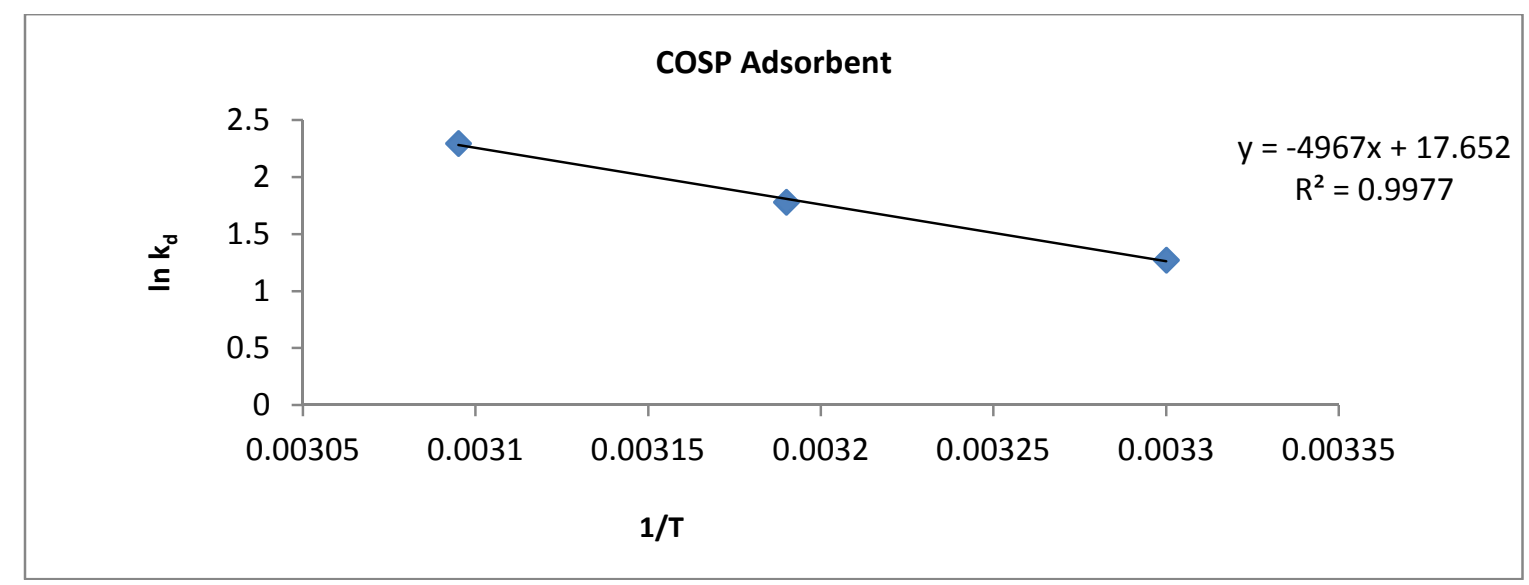

Fig.-6: 1/T Vs $\ln \mathrm{K}_{\mathrm{d}}$

Table 1: Thermodynamic Parameters

\begin{tabular}{c|c|c|c|c|c|c}
\hline Parameter & $\Delta \mathrm{H}(\mathrm{kJ} / \mathrm{mol})$ & $\begin{array}{c}\Delta \mathrm{S} \\
(\mathrm{J} / \mathrm{mol} / \mathrm{K})\end{array}$ & \multicolumn{3}{|c|}{$\Delta \mathrm{G}(\mathrm{kJ} / \mathrm{mol})$} & $\mathrm{R}^{2}$ \\
\hline Temperature $(\mathrm{K})$ & & & 303 & 313 & 323 & \\
\hline Bark Powder & 41.295 & 146.75 & -3.169 & -4.6377 & -6.105 & 0.9977 \\
\hline
\end{tabular}

The positive $\Delta \mathrm{H}$ and $\mathrm{R}^{2}$ value close to one, indicate that the adsorption process is physisorption in nature and also that the process is endothermic ${ }^{35}$. The disorder and randomness at the surface of the adsorbent are indicated by the positive $\Delta S$ value. The spontaneity of adsorption is indicated by the negative value of $\Delta \mathrm{G}$. The adsorption forces are conducive to make the $\mathrm{Al}$ ions to cross the potential barrier at the interface of the adsorbent surface and solution. With the increase in temperature, the surface thickness of the adsorbent decreases while movement of $\mathrm{Al}$ ions towards the surface of the adsorbent increases and these two aspects increase the diffusion of $\mathrm{Al}$ ions into the surface layers of the adsorbent and also into the pores in the sorbents. This penetration results in the adsorption of more $\mathrm{Al}$ ions.

\section{Analysis of Nature of Adsorption}

The adsorption nature is studied adopting Langmuir, Freundlich, Temkin and Dubinin-Radushkevich isotherms ${ }^{17,20,2834}$ and the observations are noted in Table-2. It is inferred from the Table that the Langmuir model describes well the adsorption process than any other model as its $R^{2}=0.9689$ is near to unity than the rest. Hence, adsorption is monolayer and homogenous in nature. Moreover, the $\mathrm{R}_{\mathrm{L}}$ value: 0.0212 indicates that the adsorption process is favorable as suggested by Hall et al ${ }^{36}$. Further, the values of E: $5.0 \mathrm{KJ} / \mathrm{mol}$ and B: $2.3586 \mathrm{~J} / \mathrm{mol}$ of Temkin and Dubinin- Radushkevich equations, suggest that the adsorption is 'physisorption' (nonspecific Vander Waals forces) as the E value is $<8 \mathrm{~kJ} / \mathrm{mol}$ and B values is $>20 \mathrm{~kJ} / \mathrm{mole}$.

Table-2: Different Parameters of Various Models for the Adsorption of $\mathrm{Al}^{3+}$ onto COSP

\begin{tabular}{c|c|c|c|c|c}
\hline S. No. & Adsorption Isotherms & Slope & Intercept & $\mathrm{R}^{2}$ \\
\hline 1 & Langmuir isotherms & $\mathrm{R}_{\mathrm{L}} 0.0212$ & 0.0456 & -0.0315 & 0.9689 \\
\hline \multicolumn{7}{c}{342} \\
EXTRACTION OF ALUMINUM (III) IONS FROM WASTE WATER
\end{tabular}


RASĀYAN J. Chem.

Vol. 12 | No. 1 |338 - 346| January - March | 2019

\begin{tabular}{c|c|c|c|c|c}
\hline & & & & & \\
\hline 2 & Freundlich isotherms & & 0.2123 & 1.0558 & 0.8591 \\
\hline 3 & Temkin Isotherm & B: $2.3586 \mathrm{~J} / \mathrm{mol}$ & 2.3586 & 14.304 & 0.8684 \\
\hline 4 & $\begin{array}{c}\text { Dubinin-Radushkevich } \\
\text { isotherm }\end{array}$ & $\mathrm{E}: 5.0 \mathrm{KJ} / \mathrm{mol}$ & $-4 \mathrm{E}-08$ & -7.1054 & 0.8942 \\
\hline
\end{tabular}

\section{Adsorption Kinetics}

Pseudo-first-order, pseudo-second-order, Bangham's pore diffusion model, Elovich model and Weber and Morris intra-particle diffusion model are applied as described in the literature ${ }^{17,20,37-40}$ From the plots, various parameters were calculated. The values are noted in Table- 3 .

Table-3: Various Kinetic Parameters Pertaining to the Adsorption of $\mathrm{Al}^{3+}$ onto COSP

\begin{tabular}{|c|c|c|c|c|}
\hline S. No. & Model & Slope & Intercept & $\mathrm{R}^{2}$ \\
\hline 1 & Pseudo first-order & -0.0091 & 0.7833 & 0.9882 \\
\hline 2 & Pseudo second-order & 0.0489 & 0.1804 & 0.9996 \\
\hline 3 & Bangham's pore diffusion & 0.7454 & -1.275 & 0.940 \\
\hline 4 & Elovich model & 3.249 & 3.304 & 0.981 \\
\hline 5 & Weber-Mories Intra Particle Diffusion model & 0.3038 & 16.2 & 0.765 \\
\hline
\end{tabular}

It is revealed from the Table that the Pseudo-second-order model is a better fit model as its $\mathrm{R}^{2}$.value: 0.9996 is more than the other models. Of these models, the Weber and Morris diffusion model is the least fit.

\section{Interfering Ions}

The interference caused by co-ions (in ten fold excess) that naturally exists in water, namely, $\mathrm{SO}_{4}{ }^{2-}, \mathrm{NO}_{3}{ }^{-}$ $, \mathrm{Cl}^{-}, \mathrm{PO}_{4}^{3-}, \mathrm{F}^{-}$, bicarbonate, $\mathrm{Ca}(\mathrm{II}), \mathrm{Cu}(\mathrm{II}), \mathrm{Mg}(\mathrm{II}), \mathrm{Zn}(\mathrm{II})$ and $\mathrm{Ni}$ (II) ions, has been investigated. The observations are noted in Fig.-7a and b. Sulphate, Nitrate and carbonate have marginally effected while Chlorides and Fluorides markedly interfered. But, phosphates synergistically maintained the extraction at $100 \%$. The cations interfered in the order: $\mathrm{Zn}^{2+}>\mathrm{Ni}^{2+}>\mathrm{Cu}^{2+}>\mathrm{Ca}^{2+}>\mathrm{Mg}^{2+}$.
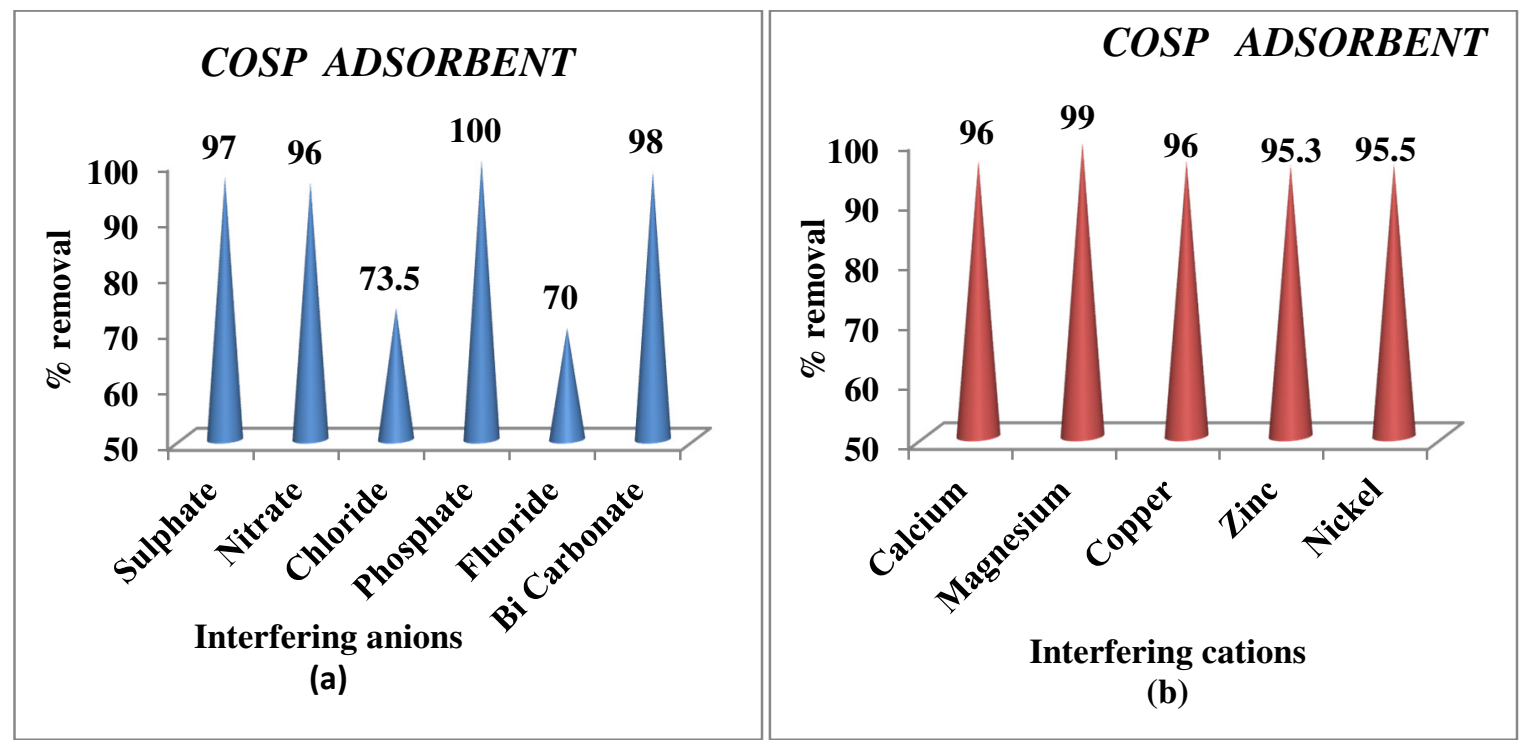

FIg.-7: (a) Effect of Interfering Anions on Adsorption of Al (III) FI. (b) Effect of Interfering Cations on Adsorption

\section{Regeneration and Reuse}

of $\mathrm{Al}(\mathrm{III})$

If the spent adsorbent is regenerated and reused, the cost of the procedure is effectively decreased. So, the regeneration of spent COSP is investigated using various eluting agents. It is found that $0.1 \mathrm{M} \mathrm{NaOH}$ is 
successful. As is evident from the Fig.-8, loss of efficiency of spent COSP is marginal until 4 recycles of regenerations. And hence, COSP can be reused up to four cycles. The \% removal Al (III) ions is found to be $100.0 \%, 98.0 \%, 97.0 \%, 96.0 \%, 84 \%, 76 \%, 65 \%$ and $50.5 \%$ respectively for 1 to $8^{\text {th }}$ regenerations.

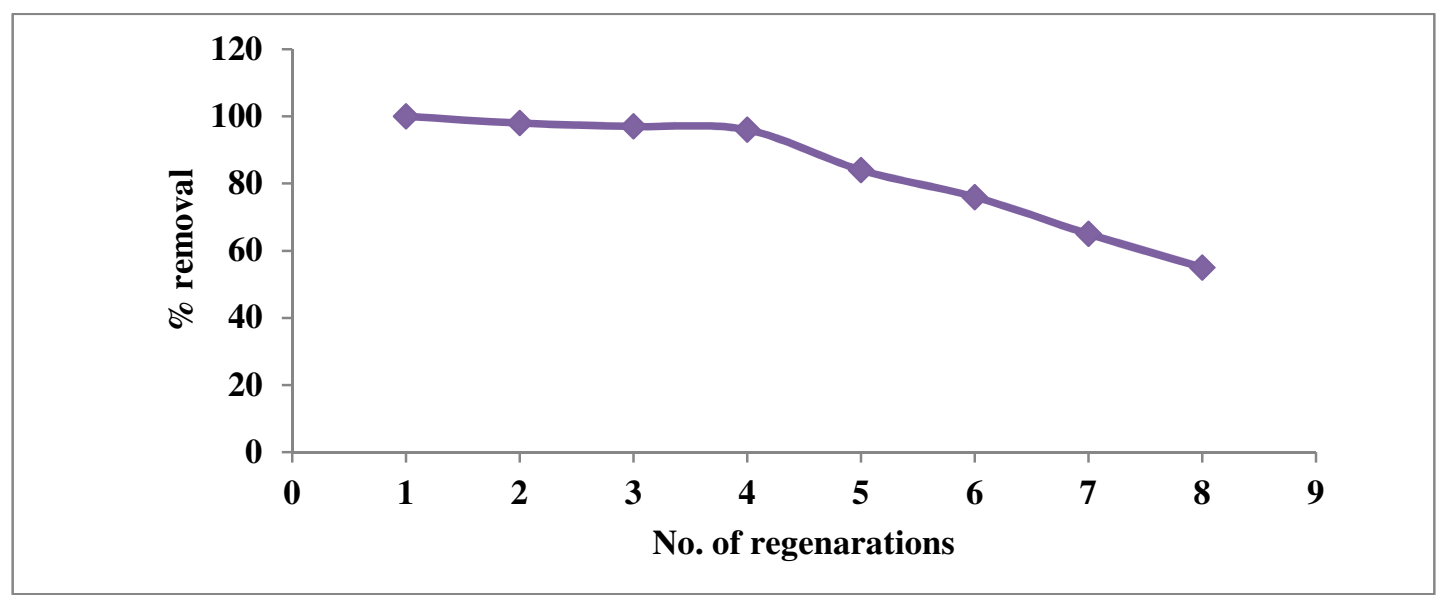

Fig.-8: No. of Regeneration Vs \% Removal

\section{Applications}

The validity of procedure developed in the present work was investigated by applying it to real polluted water samples collected at diverse sources namely, Aluminum based industries and also from the naturally contaminated water. Results are presented in Table-4.

Table- 4: Removal of Al(III) from Polluted Water Samples

( $\mathrm{pH}: 8$; COSP dosage: $2.5 \mathrm{~g} / \mathrm{L}$, time of equilibration: $120 \mathrm{~min}, \mathrm{rpm}: 300$ and temperature $28^{\circ} \mathrm{C} \pm 2^{\circ} \mathrm{C}$ )

\begin{tabular}{c|c|c|c}
\hline Samples & $\begin{array}{c}\text { Initial Al }{ }^{3+} \text { conc. } \\
\text { (in mg/L) }\end{array}$ & $\begin{array}{r}\mathrm{Al}^{3+} \text { conc. after } \\
\text { extraction (in mg/L) }\end{array}$ & $\begin{array}{c}\text { Percentage } \\
\text { removal }\end{array}$ \\
\hline Alum Industry effluents & \multicolumn{3}{|c}{} \\
\hline 1 & 10.5 & 0.5 & $95.2 \%$ \\
3 & 12.3 & 0.6 & $95.1 \%$ \\
\hline Polluted Lake Samples (having & 14.1 & 0.8 & \multicolumn{2}{c}{} \\
known conc. of $\mathrm{Al}^{3+}$ ): & & & $94.3 \%$ \\
\hline 1 & 15.0 & 1.4 & $93.0 \%$ \\
3 & 20.0 & 1.8 & $92.8 \%$ \\
\hline
\end{tabular}

As is evident from the data that good amounts of $\mathrm{Al}$ (III) are extracted and hence, the adsorbent can be used in the treatment of wastewater/ industrial effluents.

\section{CONCLUSION}

An adsorbent derived from Cassia Occidentalis plant stems is investigated for the extraction of $\mathrm{Al}^{3+}$ ions from wastewater by optimizing the extractions conditions namely, $\mathrm{pH}$, adsorbent dosage, contact time, initial conc. of $\mathrm{Al}^{3+}$ ions and temperature. With simulated water, $100 \%$ removal of $\mathrm{Al}$ ions is observed in the $\mathrm{pH}$ range 6-8 and with sorbent conc: $2.5 \mathrm{~g} / \mathrm{L}$, equilibration time: $120 \mathrm{~min}$ and temp $30^{\circ} \mathrm{C}$. Common co-cations and many anions (except $\mathrm{Cl}^{-}$and $\mathrm{F}^{-}$) have only marginal interference. It is interesting to note that substantial amounts of $\mathrm{Al}$ ions are extracted even at low $\mathrm{pH}$ values. This paves the way to apply this method even for acidic polluted water. The adsorption kinetics and nature of adsorption are investigated. Thermodynamic parameters are evaluated. The method developed is effectively applied for removing $\mathrm{Al}(\mathrm{III})$ ions from the industrial effluents and polluted samples. The adsorbent can be regenerated and reused up to four cycles. 
RASĀYAN J. Chem.

Vol. 12 | No. 1 |338 - 346| January - March | 2019

\section{ACKNOWLEDGMENT}

The authors thank the authorities of K L University, A.P., for providing needed facilities to conduct this research work.

\section{REFERENCES}

1. Anna Aruna Kumari and K. Ravindhranath, Asian Journal of Water, Environment and Pollution, 15 (1), 23 (2018).

2. W. L. Lindsay, Walthal, The Environmental Chemistry of Aluminum, Ed. G Sposito, $2^{\text {nd }}$ Ed., CRC Press, Boca Raton, Florida, p. 334 (1996).

3. A. Becaria, A. Campbell, and S.C. Bondy, S. C. 2002). Aluminum as a toxicant, Toxicology and Industrial Health, 18(7), 309 (2002), DOI: 10.1191/0748233702th157oa

4. Bi. Shuping, Analyst, 120, 2033 (1995), DOI: 10.1039/AN9952002033

5. T. P. Flaten, Brain Res. Bull., 55 (2), 187(2001), DOI: 10.1016/S0361-9230(01)00459-2

6. K.E. Haven, Can. J. Aquat. Fish Sci., 49, 2392 (1992), DOI: 10.1139/f92-264

7. J. D. Birchall, C. Exley, J.S. Chappell and M. J. Phillips, Nature (London), 338, 146 (1989).

8. Mexent ZUE MVE, Raphinos KOUYA BIBOUTOU, François EBA, David NJOPWOUO, Journal of Environment and Earth Science,.6(5), 37(2016).

9. Pranay A Raut, Anup Chahande, Yogesh Moharkar (2015).. International Journal of Emerging Trends in Engineering and Basic Sciences, 2(2), 64 (2015).

10. Mohamad nasir othman, Md. Pauzi Abdullah and Yang Farina Abi. Aziz, Removal of Aluminium from Drinking Water, Sains Malaysiana, 39(1), 51(2010)

11. Shaban El-Sayed Ghazy, Salem El-Sayed Samra, Abd El-Fattah Mohammed Mahdy, and Sherin Mohammed El-Morsy, Analytical Sciences, 22 (3), 377(2006).

12. C Septhum, S Rattanaphani, John Bremner, Vichitr Ratta, Journal of Hazardous Materials 148(1-2), 185 (2007)

13. M. W. Jayaweera , J. C. Kasturiarachchi and R. K. Kularatne , S. L. Wijeyekoon, J. Environ Management, 87(3), 450(2008).

14. A. A. Kumari and K. Ravindhranath, International Journal of ChemTech Research, 4(4), 1733(2012).

15. A.A. Kumari, K. Ravindhranath, Journal of Chemical and Pharmaceutical Research, 4(5), 2836 (2012)

16. A. Aruna Kumari and K. Ravindhranath, Der Pharmacia Lettre, 8 (8), 204(2016).

17. Sujitha Ravulapalli and K. Ravindhranath, Journal of Fluorine Chemistry, 193, 58(2017).

18. M. Suneetha, B. Syama Sundar and K. Ravindhranath, International Journal of ChemTech Research, 7(1), 93(2015).

19. M Suneetha, B Syama Sundar and K. Ravindhranath, International Journal of Environmental Technology and Management, 18(3), 420(2015).

20. Krishna Mohan, G.V., Naga Babu, A., Kalpana, K. Ravindhranath, Int. J. Environ. Sci. Technol., 16 (1), 101(2019), DOI: 10.1007/s13762-017-1593-7

21. Sujitha Ravulapalli and Ravindhranath Kunta, Water Sci Technol, 78 (6), 1377(2018), DOI: 10.2166/wst.2018.413

22. K. Venkata Pravalika, P. Janaki Sriram, P. Karunasri Meghana and K. Ravindhranath, Rasayan J. Chem., 11(4), 1750 (2018), DOI: 10.31788/RJC.2018.1145048

23. Y. Hanumantha Rao and K. Ravindhranath, Rasayan Journal of Chemistry, 10(4), 1104(2017), DOI: 10.7324/RJC.2017.1041829

24. M. Suneetha, and K. Ravindhranath, Indian Journal of Chemical Technology, 25(4), 345(2018).

25. M. Suneetha and K. Ravindhranath, Journal of Chemical and Pharmaceutical Research, 6(8), 408(2014).

26. M. Suneetha and K. Ravindhranath, Journal of Chemical and Pharmaceutical Research, 4(1), 526 (2012)

27. K. Prameela Rani and K. Ravindhranath, Journal of Chemical and Pharmaceutical Research, 6(5), 889(2014).

28. R. Sujitha and K. Ravindhranath, Journal of Environmental Chemical Engineering 6(4), 4298 (2018), DOI: $10.1016 /$ j.jece.2018.06.033 


\section{RASĀYAN J. Chem.}

Vol. 12 | No. 1 |338 - 346| January - March | 2019

29. K. Venkata Ramana, K. Swarna Latha and K. Ravindranath and B. Hari Babu, Rasayan J. Chem., 10(2), 349(2017), DOI:10.7324/RJC.2017.1021537

30. R. Sujitha and K. Ravindhranath, Journal of Analytical Methods in Chemistry, Volume 2017(2017), Article ID 3610878, 13 pages, DOI:10.1155/2017/3610878

31. G.V. Krishna Mohan, A. Naga Babu, K. Kalpana, and K. Ravindhranath, Asian Journal of Chemistry, 29 (11), 2549(2017).

32. Metcalf and Eddy, Wastewater Engineering: Treatment of Reuse. $4^{\text {th }}$. Ed., McGraw Hill Co., New York (2003).

33. A. Naga Babu, G. V. Krishna Mohanm, K..Kalpana and K. Ravindhranath, Journal of Environmental Chemical Engineering, 6, 906(2018).

34. G. H. Jeffery, J. J. Bassett, J. Mendham and R. C. Denney, Vogel's Textbook of Quantitative Chemical Analysis, Addison Wesley Longman Limited, Ed 5, 678 (1989).

35. Z. Bouberka, S. Kaoha, Kamecha, S. Elmaleh and Z. Derriche, J. Hazard. Mat., 119, 117(2005).

36. K. R. Hall, L. C. Eagleton, A. Acrivos and T. Vermevlem, Ind. Eng. Chem. Fundam., 5, 212(1966).

37. W. J. Weber Jr. and C. Morris, J. Sanit. Eng. Div., 89, 31(1963).

38. M. Ozacar and I. A. Sengil, Process Biochem., 40, 565(2005).

39. M. Suneetha, B. Syama Sundar and K. Ravindhranath, Asian Journal of Water, Environment and Pollution, 12(3), 33(2015).

40. C. Gerente, V.K.C. Lee, P. Le Cloirec and G. McKay, Crit. Rev. Environ. Sci. Technol., 37, 41 (2007).

[RJC-5064/2019] 